\title{
Determinants of Listed Deposit Money Banks' Profitability in Nigeria
}

\author{
Saheed Adekunle Muraina \\ Department of Accounting, Ahmadu Bello University, Zaria, Nigeria
}

Email address:

fortune.muraina@gmail.com, msaheed@ptad.gov.ng

To cite this article:

Saheed Adekunle Muraina. Determinants of Listed Deposit Money Banks' Profitability in Nigeria. International Journal of Science, International Journal of Finance and Banking Research. Vol. 4, No. 3, 2018, pp. 40-56. doi: 10.11648/j.ijfbr.20180403.11

Received: May 5, 2018; Accepted: June 19, 2018; Published: July 9, 2018

\begin{abstract}
This study examines internal factors affecting profitability of Deposit Money Banks (DMBs) in Nigeria for the period of 2008-2016 using panel data of 14 listed banks drawn from the Nigerian Stock Exchange. Secondary data obtained from the listed Deposit Money Banks' financial statements were analyzed. The independent variables were proxied by Capital Adequacy, Credit Risk, and Inflation while profitability was proxied by Return on Assets (ROA). The study adopts correlational research design to investigate the determinants of profitability of the Deposit Money Banks. Panel data techniques (fixed and random effects model) were employed to examine the effect of internal factors on profitability of the sampled listed Deposit Money Banks. Although Hausman specification test suggested that fixed effect model is more appropriate, the study used Feasible Generalized Least Square (FGLS) to underpin the outcome of the Hausman specification. The study found that internal factors had significantly influenced the deposit money banks' profitability over the study period. The Capital Adequacy had a positive and significant relationship with bank profitability while Credit Risk had a negative and significant relationship with bank profitability during the study period. It is therefore suggested among others that the Central Bank of Nigeria (CBN) should maintain a central database called Credit Risk Management System across banks in the country, which would be generating accurate and reliable credit information on bank borrowers as a way of evaluating the repayment capabilities of the customers to be granted credit facilities.
\end{abstract}

Keywords: Bank Profitability, Feasible Generalized Least Square, Capital Adequacy, Credit Risk, Deposit Money Banks

\section{Introduction}

\subsection{Background to the Study}

Changes have become inevitable to the banking sector globally. These are perhaps, due to changes in government policies, globalization, information technologies, economic and financial deregulation among others. Particularly, the banking system in Nigeria has witnessed series of issues and challenges. These range from banking consolidations, global financial crisis in 2007/08 as well as bank recapitalization and of recent, ever changing Nigerian government policies.

Ongoing reforms of the banking industry in Nigeria have shown weaknesses in the country's financial service industry. The country's banking industry is essentially characterized by holding lesser capital than required by laws and regulations, over-aggressive lending practices and hazardous risk tolerances, poor risk management practices as a result of weak control measures as well as stiff competition and uncoordinated bank expansion programme together with the rapidly changing economic environments. These elements engender the need for a further study of determinants (capital adequacy, credit risk and inflation) on bank profitability.

During the period under study, continued fall in the performance of major macroeconomic determinants, precisely inflation has led to a marginal decrease in profitability of banks in Nigeria. Also, the listed Deposit Money Banks under study have been operating in an unstable economic environment because interests charged by them are mainly absorbed by inflation in the country. Apart from that, insider loans and over concentration in some portfolios increase, leading to an increase in credit risk. Therefore, this study seeks to stress the connection among capital adequacy, credit risk and inflation because they are critical for banking business survival. 
This research work intends to examine crucial bank-specific determinants and their effect on profitability of the listed Deposit Money Banks (quoted Commercial Banks) in Nigeria. Studies on determinants (capital adequacy, credit risk and inflation) and their effects on banks' operations in Nigeria are scanty. So, this study intends to fill this research gap by examining how those determinants influence banks' profitability.

There are several studies, \{Ifuero and Chijuka (2014); Ayanda, Christopher and Mudashiru (2013); Aminu (2013); Kanwal (2013); Kalluci (2011); Mathuva (2009) among others\}, which showed that both bank-specific and macroeconomic determinants affect Deposit Money Banks' profitability. Bank-level factors such as capital adequacy and credit risk as well as a control variable (inflation) will be employed in this study to determine the profitability of Deposit Money Banks in Nigeria over the period under study.

The study of the Nigerian banking sector is therefore, of immense importance with a view to establishing the relationship as well as the effect of bank-specific determinants on bank profitability. So, this study will dwell on determinants such as capital adequacy, credit risk and inflation as they affect banks' profitability in Nigeria.

This study is principally inspired by the fact that it will serve as a policy guide in the Nigerian Banking Industry because there is no adequate and exhaustive information available for policy makers on banks' profitability in the country that would be used as guidance in her Banking sector. The findings of this study will significantly add to the body of knowledge regulating finance decisions in the country under study. It will also contribute to the controversial academic debates concerning which internal and external determinants influence banks' profitability.

\subsection{Statement of the Problem}

Bank-specific factors, which influence profitability levels of the listed Deposit Money Banks in Nigeria, require further investigations among researchers with a view to further addressing the issue of determinants of bank profitability. So, Ani, Ugwunta, Ezeudu and Ugwuanyi (2012) suggested that additional variables such as credit risk, and inflation should be included in determining bank profitability. The recommended variables have therefore, been incorporated in this paper.

The focus of this study will also centre on Nigeria because most researches of this kind are carried out in advanced economies and few, in developing countries such as Nigeria. Stephen, Kolapo and Aluko (2014) were of the view that a wider coverage needs to be considered in determining factors affecting bank profitability through an increase in the number of banks in the sample and the span of the study on determinants of bank profitability. In essence, this study intends to duly cover the gap in the literature by widening the scope to the coverage of fourteen (14) listed banks on Stock Exchanges in Nigeria for nine years.

Besides, to the best of the researcher's knowledge, there is no known previous empirical study on determinants of banks' profitability in Nigeria that has specifically related its research to the profitability of listed Deposit Money Banks in Nigeria within the period under study. Due to the unique features of banks in relation to their operations, irrespective of their environments, there are strong evidences for further studies on determinants (capital adequacy, credit risk and inflation) of bank profitability. The debate on determinants of bank profitability is still open because they constitute unresolved issues in accounting and finance literature.

\subsection{Objectives of the Study}

The main objective of the study is to investigate determinants of profitability of listed Deposit Money Banks in Nigeria. Specifically, the study is to:

i. Examine the effect of Capital Adequacy on profitability of listed Deposit Money Banks in Nigeria.

ii. Identify the effect of Credit Risk on profitability of listed Deposit Money Banks in Nigeria.

iii.Examine the effect of Inflation on profitability of listed Deposit Money Banks in Nigeria.

\subsection{Hypotheses of the Study}

In line with the objectives of the study, the following hypotheses have been formulated in null forms.

$\mathrm{H}_{1}$ : Capital adequacy has no significant effect on profitability of listed Deposit Money Banks in Nigeria.

$\mathrm{HO}_{2}$ : Credit risk has no significant effect on profitability of listed Deposit Money Banks in Nigeria.

$\mathrm{HO}_{3}$ : Inflation has no significant effect on profitability of listed Deposit Money Banks in Nigeria.

\subsection{Scope of the Study}

The study would examine determinants of profitability of listed Deposit Money Banks in Nigeria for the period of 2008 to 2016. The independent variables of the study are capital adequacy, credit risk and inflation while the dependent variable of the study was proxied by return on assets. The listed Deposit Money Banks were chosen as a domain of the study because of their strategic importance to Nigerian economy in terms of providing financial services for higher profitability and national economic benefits in Nigeria. The period of the study was selected because it covered the period of unstable economic development in Nigeria.

\subsection{Significance of the Study}

The studies that concentrate on the financial sector of Nigeria are few. Based on the best knowledge of the researcher, there is no known study conducted that exactly examines the determinants of listed Deposit Money Banks' (Deposit Money Banks) Profitability conclusively in Nigeria over the study period.

However, if there are some papers on that, they cannot be the same due to the period; data; factors and methodology used, and the conclusions also may not be the same. Hence, the need to carry out this research.

\subsection{Related Literature}

The research works specifically on internal factors and 
their effects on profitability of banks are world-wide many. This study will only select those that could serve as a guide to the model specification of this empirical work. The literature review will help to show-case related studies to the variables used in this research.

The researcher will therefore dwell on studies relating to variables vis: Capital Adequacy, Credit Risk and Inflation as they influence profitability of listed Deposit Money Banks in Nigeria. This section will specifically carry out a review of conceptual issues in sub-section 1.7.1, measurement of profitability in sub-section 1.7.2, empirical studies in subsection 1.7.3 and theoretical framework in sub-section 1.7.4 of this study.

\subsubsection{Conceptual Issues}

The major rationale behind the establishment of business enterprises is the profitability. Basically, profitability consists of two words, which are profit and ability. The term profit is concerned with receipts less costs, whereas ability is the power of a business enterprise to generate profit on sales of goods or provision of services. Profit is expressed in absolute terms while profitability is expressed in relative terms.

In farm accounting, profitability is measured through farming gross margin relative to total farm asset values. Conversely, in a manufacturing setting, profitability is obtained using gross profit to net sales ratio or operating profit to net sales expressed in terms of percentage. On the other hand, in banking sector, profitability is arrived at through Net Interest Margin, Return on Equity or Return on Assets. In essence, there is no single basis for measuring profitability because it all depends on who is measuring profitability and for what purpose. In this study, profitability will be measured using the return on assets (ROA) as employed by Molyneux and Thornton (1992); Athanasoglou, Brissimis and Delis (2005) and expressed as a function of firm-level and macroeconomic factors.

\section{i. Capital Adequacy}

Capital adequacy is the amount of capital required for a bank as stipulated by the regulatory and supervisory authorities in order to achieve the banks financial health and soundness. In the insurance sector, capital adequacy implies the capital that is required to reduce the probability of insurer defaults to some certain levels. On the other hand, in the manufacturing setting, capital adequacy is the one that is necessary for operation and is usually represented by $\log$ capital reserve, measured by retained profits plus depreciation. In the banking sector, capital adequacy is measured through Tier one plus Tier two divided by Risk Weighted Assets. Tier-One capital (Share Capital) is the one, which can absorb losses without requiring the affected bank to close trading, but Tier-Two capital (preference share and subordinated debt) is the one that can absorb losses in case of bank liquidation, thereby providing depositors a lesser level of protection. In line with Basel 3 provisions, banks' capital requirement is necessary to be between $8 \%$ and $10.5 \%$. Another measure of bank capital adequacy is equity to total assets and will be adopted by this study in line with (Ejoh and Iwara 2014), (Mustafa and Bassam 2012), (Abreu and Mendes 2001), (Kosmidou 2008) among others.

\section{ii. Credit Risk}

The idea of credit risk is really incontrovertible across financial services entities. Therefore, a loan loss provision is an amount, which is set aside for uncollected loans or credits. It is calculated as loan loss provision to total loans. The level of loan loss provision to total loans makes the bank managers to know their expectation about bank's asset quality. When giving out loans, banks are conscious of the fact that borrowers could default, thereby not able to fully pay up the loan. When it shows that the borrowers may not redeem their loans, a bank will set aside a 'provision' to be charged to the income statement, which then appears on the face of the statement of financial position as a loan loss reserve. If a customer defaults eventually, the loan balance would then be reduced by making a charge to the loan loss reserve. The higher the ratio, the lower is the asset quality and vice versa. In this study, the loan loss provision to total loans will be used to measure credit risk, which is consistent with (Million, Matewos and Sujata 2015), (Ahmed, Riaz and Muhammad 2012), (Fan 2014), (Ishmael 2015), (Manel 2015), (Ahmad 2007) and (Boahene, Dasah and Agyei 2012)

\section{iii. Inflation}

The concept of inflation is generally incontrovertible and it is therefore, a situation where there is a persistent rise in the general level of prices or a decline in the value of money over a period. In other words, inflation is the pervasive and continuous rise in the aggregate level of prices measured by an index of the cost of various goods and services, occasioned by wars, religious unrest, political instability, poor harvests, environmental upheavals kidnapping and other social malaise.

\subsubsection{Measurement of Profitability}

Bank profitability is a measure of bank performance. It was proxied by Return on Asset (ROA) in this study. ROA is an essential indicator normally employed in determining the performance of Deposit Money Banks particularly. Return on Assets (ROA) is an essential indicator of bank profitability. The higher this ratio, the better the profitability of banks (Herry, 2015). It is computed through dividing Profit after tax by total assets. ROA shows how banks are able to generate income from their assets. ROA may notwithstanding, be biased because of off-balance sheet activities, (Samuel 2015). However, the principally used variable for determining bank performance is the Return on Assets (ROA) because it is not misrepresented by high equity multipliers. ROA is therefore a common indicator of bank profitability (Deger and Adem, 2011). ROA will be used extensively in the analysis of the research result in this research work.

\subsubsection{Empirical Review}

There exist many schools of thought on determinants of bank profitability and the influence of such on the bankspecific and macroeconomic indices of a country. Some studies on determinants of bank profitability concentrate on a 
single country while some others focus on cross-country studies. In this sub-section, research works on bank profitability were presented hereunder on a variable by variable basis so as to make this research work more encompassing.

\section{i. Capital Adequacy and Profitability}

Capital is an essential variable in determining bank profitability or financial performance. Capital adequacy is the amount of capital that is essential for a bank as determined by the regulatory and supervisory authorities to assume the banks financial health and soundness (Ejoh and Iwara, 2014). So, capital adequacy is the capital required by a country's Apex Bank to be held by a deposit money bank or any other financial institution in order to reduce the bank's exposure to insolvency risk and also to guarantee the efficiency and stability of the country's financial system. The required capital can be Tier one or Tier Two. The former can take in losses without a bank going under while the latter can absorb losses in case of liquidation.

Agbeja, Adelakun and Olufemi (2015) found a positive and significant relationship between capital adequacy and bank's profitability using Nigerian banks from 2010 to 2014 . This supports the argument that banks with higher capital enjoy higher profitability, financial soundness and safety. Therefore, a strong capital structure is essential for banks in developing countries with a view to having enough strength to cope with any financial crisis, (Isaac, Samuel and Mailafia 2014). This will enable depositors feel secured in case of any economic instability.

Further, Isaac, Samuel and Mailafia (2014) reported a positive but insignificant relationship between capital adequacy and bank's profitability. Secondary data of 14 listed deposit money banks in Nigeria from 2005 to 2012 was employed. The study employed correlation research design. In examinining the relationship between profitability (dependent variable) and bank-specific factors (independent variables), ordinary least square (OLS) regression model was conducted. However, the study failed to test for Fixed Effect and Random Effect estimates, associated with panel data regression. Therefore, Ordinary Least Squares (OLS) estimate could lead to biased result, (Christos and Geoffrey 2011) about determinants of bank profitability.

Also, Stephen, Kolapo and Aluko, (2014) investigated the determinants of bank profitability- panel evidence from Nigeria. The study used panel data method to examine time series and cross-sectional data obtained from 2000 to 2013 on a sample of 14 listed deposit money banks in Nigeria. A positive but insignificant relationship between capital adequacy and bank's profitability was shown but was spuriously analyzed as being significant in the research conclusion.

Similarly, Ejoh and Iwara (2014) investigated the impact of capital adequacy on Deposit Money Banks' profitability in Nigeria, using secondary data of five selected banks from the period 1981 to 2011. The study used the Engle and Granger two steps procedure in co-integration. The research findings showed a positive and significant relationship between capital adequacy and banks' profitability, implying that banks with equity financing appear to have more safety and subsequently, higher profitability. It was then, recommended that Nigerian banks should be well capitalized for cheaper sources of funds and for improvements in returns. However, the result of an investigation conducted with only five banks and equally carried out only during the pre-IFRS adoption era in Nigeria may not be used for generalization in a region such as Nigeria.

In the same vein, Khaled and Samer (2013) examined the determinants of capital adequacy in Deposit Money Banks of Jordan for the years 2000 to 2008 using annual reports of banks listed on Amman Stock Exchange. Multiple linear regression analysis was employed to ascertain the factors that mostly affect the degree of capital adequacy. Pearson Correlation Coefficient was also used to determine the directions of the expected relationship between independent and dependent variables.

Conversely, Chris (2010) examined the relationship between profitability and capital adequacy of all licensed Commercial Banks in Kenya from 2004 to 2009. Profitability was measured using ROA and ROE while capital adequacy was represented by the capital asset ratio. The regression model was applied for the analysis. It was then, reported that there is a significant negative relationship between capital adequacy and ROA while insignificant relationship was found between capital adequacy and ROE. It was then suggested as areas for further research, that a similar study could be conducted over a longer period of time, which would also focus on the impact of the macro-economic environment such as inflation and GDP because they do influence bank profitability. Nonetheless, the result of the study may not be used for generalization in a region such as Nigeria because it was conducted before and during the global financial crisis, leaving the events after the crisis un-investigated.

Nonetheless, Flamini, McDonald and Schumachers (2009) carried out a study on the Determinants of Deposit Money Banks' Profitability in Sub-Saharan Africa (SSA) using data obtained from financial statements of individual banks provided in the Bank-Scope-Database from 42 countries and 216 Deposit Money Banks for the period 1999 to 2006. The rationale behind his study was a lack of empirical information on commercial banking in Sub-Saharan Africa while extensive researches have been done on bank performance in advanced economies. Bank-specific variables used include bank asset growth in assets, capital adequacy, credit risk, operating efficiency, liquidity ratio and macroeconomic variables used comprise growth in GDP and inflation.

The study employed panel methods of Fixed Effects (FE), Random Effects (RE) and Feasible Generalized Least Squares (FGLS) in a static framework. It was found that capital adequacy had a positive influence on bank profitability. It was therefore, concluded that bank privatization should be encouraged since privately-owned banks have potentials of gaining higher returns than their 
publicly-owned counterparts. It was remarked that such high profits should be invested (to form part of subsequent equity). It was also recommended that higher capital requirements should be enforced on banks in SSA to enhance financial stability in the sub-region. Although, the study captured countries such as Nigeria, but was conducted before the 2007/08 global financial crisis, which could have undermined its relevance in the present day banking business due to various subsequent reforms on banks' minimum capital requirement, mergers and acquisitions among others that have emerged in the country.

Other studies that reported a positive relationship between capital adequacy and profitability are Berger (1995); Hassan and Bashir (2005); Athanasoglou, Brissimis and Delis (2005); Sayilgan and Yildirim (2009); Davydenko (2010); Ani, Ugwunta, Ezeudu and Ugwuanyi (2012); Osborne, Fuertes and Milne (2013); Ikpefan (2013), Ejoh and Iwara (2014), Tuzcu (2015), Johannes (2015), Tamim, Haque and Alam (2016). Other studies that found a negative relationship between capital and profitability include Khalid (2011), Paolo (2011), Muhammad (2011), Xuezhi and Pastory (2012), Almumani (2013).

It is therefore hypothesized that capital adequacy will have a positive relationship with bank profitability and this is in line with the trade-off theory of capital structure, which states that in under-stressed conditions, banks may be able to improve their profitability by increasing capital ratios. It is also in consonance with Capital Adequacy Buffer Model (CABM), which helps to analyze the effect of Capital Adequacy on the dependent variable (ROA and ROE) proposed by David, Michael, Robert and Abhay (2013) and used by Ikpefan (2013).

\section{ii. Credit Risk and Profitability}

Credit Risk is represented by Loan Loss Provisions to Gross Loans. Moody's Investor Service (2011) and it is used to amend loan loss reserves.

Lucky and Nwosi (2015) investigated the relationship between asset quality and the profitability of the fifteen (15) quoted Deposit Money Banks in Nigeria from 1980 - 2013 using Secondary data were sourced from annual reports of the quoted Deposit Money Banks. Multiple regressions with econometric view statistical package were employed as data analysis method. The Ordinary Least Square properties of Augmented Dickey Fuller Test, Co-integration and Granger Causality test were used to ascertain the short and long-run relationship between the dependent and the independent variables. Findings from the regression result showed that percentage of Loan Loss Provision to Total Loans has a negative relationship with Return on Investment of the Deposit Money Banks. The study suggests that bank lending environment should be well examined before and after credit. Also, the regulatory authorities are enjoined to ensure sound bank lending environment to avoid the incidence of non-performing loans to improve the profitability of Deposit Money Banks in Nigeria.

Also, Kolapo, Ayeni and Oke, (2012) examined the quantitative effect of credit risk on the performance of five Deposit Money Banks in Nigeria over the period of 11 years
(2000-2010) using the traditional profit theory to formulate profit, represented by Return on Asset (ROA) against the ratio of loan loss provision to classified loans (LLP/CL) as measures of credit risk. Panel model analysis was employed to estimate the determinants of the profit function. The result indicated that there is a negative and significant relationship between credit risk and bank profitability. It was then advised that banks in Nigeria should improve their capacity in credit analysis and loan administration while the regulatory authority should ensure banks comply with relevant provisions of the Bank and other Financial Institutions Act (1999) and prudential guidelines. However, an investigation using only five banks may not be appropriate enough for generalizing the result of the study for banks' decision making.

On the contrary, Million, Matewos and Sujata (2015) empirically investigated the impact of credit risk on profitability performance of eight selected Deposit Money Banks in Ethiopia using secondary data from the annual reports of the chosen banks for the years 2003-2012. Descriptive statistics and panel data regression were used to analyze the data. It was found that credit risk had a positive and significant relationship with profitability, implying that lending business in the country's banks could be risky; though, it is associated with high returns. It was then recommended that a rigorous risk management process should be followed and modern risk management technique should be used as well, when giving out loans. Nevertheless, the abstract of the study presented study of 2003-2004. The conclusion showed 2003-2012 study period while the research design and methodology section reported study period of 2001-2012, thereby not presenting the writing style of the research in a logically consistent manner.

However, Noman, Pervin, Chowdhury and Banna (2015) examined the effect of credit risk on profitability of the banking sectors of Bangladesh using an unbalanced panel data and 172 observations from 18 private Deposit Money Banks from 2003 to 2013. The OLS, random effect model, GLS and system GMM were employed to analyze the panel data. It was then reported that credit risk negatively influences the profitability of the Deposit Money Banks. It was recommended that banks should apply prudent credit risk management procedure in order to enhance profitability.

It is therefore hypothesized that there is a negative and significant relationship between credit risk and bank profitability as reported by Ahmed, Riaz and Muhammad (2012); Kolapo, Ayeni and Oke (2012); Fan (2014); Ishmael (2015); Manel (2015); Lucky and Nwosi (2015).

\section{iii. Inflation and Profitability}

Inflation occurs when cost of goods and services is more than the living standard of a country. Inflation demoralizes investors and also causes a negative effect on the market (Muhammad and Naeem 2015). Christos (2004) is of the view that inflation causes customers' changes in the demand for various types of banks' financial services and unanticipated rises of inflation bring about cash flow issues to borrowers, which can cause them to end the loan arrangements abruptly, 
thereby leading to loan losses to the banks. Uncertainty about future inflation is bound to affect a bank loan negotiation. This is due to the fact that a rise in anticipated inflation increases the nominal interest rate, (Santoni 1986).

Anna and Chan (2009) investigated the impact of bank characteristics as well as macroeconomic and financial structure variables on the performance of the Macao banking industry. It was reported that Inflation is the only macroeconomic variable that shows a significant relationship with banks' performance, represented by return on assets. This result may indicate that the rate of inflation was expected by bank management and they accordingly factored it into their banking operations, making them to be more profitable in inflationary environments. This further implies that a bank's returns increase more with inflation than its expenses.

One of the recent studies conducted was that of (Naser and Abdollah, 2015) in which the impact of Inflation on profitability of banks was examined from 2010 to 2013 using Generalized method of moments (GMM) to estimate the research model. The study result showed a strong correlation between inflation and banks' profitability. The study period was short implying that the result cannot be generalized on banks in a sub-region such as Nigeria.

Similarly, Naser and Moghanloo (2015) examined the impact of internal and external factor and macroeconomic variables on profitability of twenty-six (26) Deposit Money Banks of Pakistan from 2008 to 2012 using panel data analysis of 130 observations. The study result showed that there is a positive relationship between inflation and profitability of Pakistani Deposit Money Banks. It was equally remarked that the inflation in the country was expected already and interest rates were also expected to be modified for the purpose of banks' profitability. It was further observed that revenue grew faster than cost during the period of the study. The period of the study on the determinants of bank profitability could have been expanded beyond five years for the result generalization.

Contrarily, Samy (2003) investigated the determinants of Tunisian Banking Industry Profitability from 1980 to 2000. The findings of the study among others showed that inflation rate has no effect on bank's interest margins and profitability.

On the other hand, Flamini, McDonald and Schumacher, (2009) studied the determinants of Commercial Bank Profitability using a sample of 389 banks in 41 countries in Sub Saharan Africa (SSA). It was opined that inflation lowers credit expansion by adding to higher net interest margins. It was then found that inflation has a positive impact on bank profits, implying that banks predict future inflationary changes accordingly while adjusting interest rates and margins. In order to promote financial intermediation, it was recommended that macroeconomic policies that could control inflation should be prioritized so as to enhance stable output growth for credit expansion and banks' profitability. The study period was between 1999 and 2006, which is about a decade past, the research result needed to be brought to date.

Inflation may be negatively or positively related to profitability depending on whether it is anticipated or unanticipated Perry (1992). The position of the Positivists' theory is that inflation has a positive and significant effect on investment decision of organizations. Therefore, inflation is viewed to be encouraging investment and consequently giving rise to a more rapid economic growth through redistribution of income from wages to profits for the purpose of investment as argued by Griffiths (1979). In line with this argument and since most studies report a positive association between inflation and bank profitability, it is posited that the relationship between inflation and profitability will be positive in this study; otherwise, negative report will be found.

The correlation between bank-specific and macroeconomic variables and banks' profitability is elucidated by the foregoing discussions. There are several volumes of literature on bank performance world-wide but infinitesimal amount of such literature is available in developing economies, particularly in Nigeria. Using previous empirical studies to assess the impact of each explanatory variable affecting bank profitability has been able to shed more light on the need for further research on the subject in Nigeria.

\subsubsection{Theoretical Framework}

This sub-section will present theoretical explanations on bank profitability such as the Structure Conduct Performance (SCP) model, efficiency hypothesis, Agency theory as well as Bank Production Approach. However, the main focus of this study is to concentrate on theories or models that capture how both internal and external factors influence bank profitability as stated below.

\section{i. The Structure-Conduct-Performance (SCP) Theory}

States that as bank size increases, economies of scale also increases, which subsequently enhances bank mergers and its related monopoly profits. Several studies have employed Structure Conduct Performance (SCP) paradigm on bankspecific and industry-specific determinants because of its applicability to contestable markets, firm-level performance and the roles of ownership and governance vis-a-vis banks' performance, (Francis 2012).

\section{ii. Efficient Structure Hypothesis (ESH)}

ESH is conversely of the view that common facilities such as ATM among banks can be shared so that capital cost will not be duplicated. Based on this, mergers among banks will become unnecessary because sharing facilities will bring about economy and efficiency in the use of their capital resources. What brings about bank profitability is the bank efficiency and not the market concentration, (Grygorenko 2009).

\section{iii. The Agency Theory}

Jensen and Meckling (1976) proposed a theoretical explanation on how ownership structure is related to profitability. The Theory therefore, presented how owners and managers in a principal-agent relationship could differ in both needs and preferences. The implication of the theory on bank profitability is that ownership structure and corporate governance structure have an impact on performance. This indicates that stringent and value-based banks could be 
earning higher profits than mutual, co-operative or stateowned banks, (Samuel 2015).

\section{iv. Portfolio Regulation Theory}

This study also presents the theory of portfolio regulation as adopted by (Ikpefan 2013) in assessing the bank profitability. The theory emphasized the necessity for the regulation of banks so as to ensure safety and soundness of the banking system.

\section{v. Bank Production Approach}

This theoretical framework will also serve as cost minimization/ profit maximization model for the banking firms under study. There are three common approaches to bank performance. These are:

The Production Approach.

This is a situation in which banks are considered to be service providers to customers. Here, inputs consist of labour, material, space, information and their associated costs while outputs are a number of deposits and loan accounts, number and type of transactions documents processed or specialized services. Production approach is used mainly for studying the efficiency of bank branches.

Intermediation Approach.

Here, banks are regarded as intermediaries of the funds between depositors and the investors. Under intermediation approach, input consists of operating and interest expenses while output comprises loans and other major assets.

Modern Approach.

In this case, there is an integration of measures of risk, agency cost and quality of bank services. Under this approach, inputs are defined as the total expenses (interest and operating expenses) while outputs are described as the total revenue (interest and non-interest). Modern Approach has sub-approaches vis:

The Ratio-Based CAMEL Approach: this uses the financial data to gauge banks' performance.

The Operating Approach or Income-Based Approach: defines banks as business units that have prime objective of getting revenue from the total cost sustained in running the business.

The appropriateness of an approach is predicated upon certain circumstances. However, the Operating Approach, which describes revenues as outputs and expenses as inputs will also be considered in this study in describing inputs and outputs of banks as adopted by Jemric and Vujcic (2002), Das and Ghosh (2006). Precisely, inputs are viewed as selling, general and administrative expenses and cost of investment and financing while outputs are viewed as revenues obtained from investments and other assets.

\section{Methods}

This study used panel data from annual audited reports and macroeconomic data of the exchange-listed selected Deposit Money Banks in Nigeria that cover period 2008-2016. This section will present research design in subsection 2.1, population and sample size of the study in the sub-section 2.2, sources and methods of data collection in sub-section 2.3 , technique of data analysis in sub-section 2.4, model specification in sub-section 2.5 and robustness tests in sub-section 2.6.

\subsection{Research Design}

The study employed correlational research design because it attempts to establish the relationship between independent variables proxied by capital adequacy, credit risk and inflation and the dependent variable proxied by return on assets of listed Deposit Money Banks in Nigeria.

\subsection{Population and Sample Size of the Study}

The population of the study contains the 15 listed Deposit Money Banks in the Nigeria as at December, 2016 while the sample size is 14 with 125 observations as attached in the Appendix to this study. While obtaining the sample, banks that were quoted on the Nigerian Stock Exchange for the time period 2008-2016 and whose data was available for the period of study were focused on.

As at 31st December, 2016, the listed Deposit Money Banks on the Stock Exchange of Nigeria were fifteen (15) while fourteen (14) listed Deposit Money Banks between 20082016 were selected based on the availability of data. A filtering technique was applied as follows: Deposit Money Banks quoted as at 1st January, 2008 and still remain listed as at 31 st December, 2016 on Stock Exchange in Nigeria were included depending on the availability of data.

\subsection{Sources and Methods of Data Collection}

A bank-specific data, consisting of a sample of 14 listed banks incorporated on or before 1st January, 2008 and are on active largest Stock Exchange in Nigeria from 2008 to 2016 were assembled leading to a panel data of 125 observations.

\subsection{Techniques of Data Analysis}

The Regression technique was applied for the data analysis in this study by using Stata statistical software. As a way of avoiding biased and spurious result, (Christos and Geoffrey 2011), the research data was run using either Fixed Effect or Random Effect Model. Hausman Test was applied to ascertain the best model for robustness and generalization of hypothesis ratio (s). Hausman test was conducted under the following hypothesis:

$\mathrm{H} 0=$ random effect model result is accepted.

$\mathrm{H} 1$ = fixed effect model result is accepted.

A P-value of 0.05 or less would allow us to accept the result of fixed effect model; otherwise, random effect would be accepted.

The appropriateness of either of the models was based on Hausman test recommendation because the Hausman specification test guides in selecting appropriate panel data model either fixed effects method or Random effects model, (Susan 2014). If the prob $>$ chi2 is significant at $5 \%$, Hausman test implies using Fixed Effect but if not significant, then Random Effect model would be used. Although Random Effect indicates some level of efficiency, Fixed Effect is a better estimator when compared with pooled OLS because it 
implies that there could be fixed differences between Deposit Money Banks across Nigeria.

Furthermore, the Fixed Effects (FE) model is considered to be an appropriate specification if the research focus is on a specific set of $\mathrm{N}$ firms and the researcher's inference is restricted to the behavior of these sets of firms. The WithinGroup Estimator of the Fixed Effect model could then be applied to reveal the impact of the internal characteristics of each bank and each year.

If the Hausman test suggests the use of FE model in this study, Feasible Generalized Least Square (FGLS) model would be applied with LR test to corroborate FE result because Feasible GLS is more efficient than Least Square Dummy Variable (LSDV) for all but the fewest degrees of freedom, (Baltagi 2005). The FE estimations are carried out by the generalized least squares (GLS) technique, which is especially appropriate for data sets where serial correlation and/or heteroskedasticity might occur, (Anna 2009).

\subsection{Measurement and Definition of Variables}

The variables for this study were selected based on usercost approach by considering bank input and output indices for determining bank profitability. The dependent variable was represented by profitability in form of Return on Asset (ROA) while the explanatory variables comprise internal and external factors such as Capital Adequacy, Credit Risk and Inflation. For the purpose of this research, ROA was estimated. The variables used in this current estimation are therefore explained below in a tabular form.

Table 1. Description of the variables and their expected relationship.

\begin{tabular}{llll}
\hline Variables & Measure & Notation & Expected Impact \\
\hline $\begin{array}{l}\text { Dependent variables: } \\
\begin{array}{l}\text { Return On Asset } \\
\text { Independent Variables }\end{array}\end{array}$ & Profit After tax/ total asset of the bank in year t & ROA & NA \\
$\begin{array}{l}\text { Capital adequacy } \\
\text { Credit Risk }\end{array}$ & $\begin{array}{l}\text { Equity/ total assets of the bank in year t } \\
\text { Loan loss provisions/ Total loans of the bank in year t }\end{array}$ & CAD & + \\
Inflation & Each Country's Annual Inflation Rate & NAF & - \\
\hline
\end{tabular}

\subsection{Model Specification}

In order to determine the effect of bank-specific variables on bank profitability in Nigeria, a multiple linear model is established. The model summarizes the influence of Capital Adequacy, Credit risk and inflation (control variable) on bank profitability. In this study, the bank-level factors affecting the profitability of Deposit Money Banks in Nigeria were assessed from the data collected and the values obtained were then substituted in the model of the study stated below in line with previous studies such as Shehu and Musa (2014), Ahmad (2014), AlGhusin (2015), Olaoye (2015) but modified to suit the best purpose of this research.

Model:

$$
\mathrm{ROA}=\beta_{\mathrm{o}}+\beta_{1}(\mathrm{CAD})_{\mathrm{ij}}+\beta_{2}(\mathrm{CRISK})_{\mathrm{ij}}+\beta_{3}(\mathrm{INF})_{\mathrm{ij}}+\varepsilon
$$

Where:

ROA $=$ Return On Assets $=$ Profit after Tax to Total Assets

$\beta_{0} \beta_{1}, \beta_{2}$ and $\beta_{3}$, denote regression parameters and slope of the variables.

$\mathrm{CAD}=$ Equity to Total Assets (Capital Adequacy) at Time i, Bank j

CRISK $=$ Loan loss provisions/ Total loans at Time $\mathrm{i}$, Bank $\mathrm{j}$

$\mathrm{INF}=$ Each Country's Annual Inflation Rate

$\varepsilon=$ The Error Term

\subsection{Robustness Test}

After specifying the model for the study, the robustness test was conducted to ascertain the validity and reliability, fairness, significance and appropriateness of the model for assessing bank profitability in Nigeria using statistical and econometric techniques such as Correlation Analysis, Regression Analysis,
Multicollinearity Test, Inferential Analysis (T-test). The data was analyzed by using Stata statistical software package to determine factors influencing bank profitability in Nigeria.

\subsubsection{Fixed Effect, Random Effect and FGLS}

Ordinary Least Square (OLS) is usually used to estimate the parameters of a single - equation model. Besides, the estimator yields estimates that are best, linear, and unbiased estimators (BLUE) with the desirable properties of consistency, efficiency and being unbiased. However, these properties are made possible after all the assumptions of the OLS method have been satisfied, (Ifuero and Chijuka 2014). By following the path of (Jim, Eric, Tom and Choi 2006) in estimating the equation for the study, Feasible Generalized Least-Squares (FGLS) procedure was used in confirming further the output of FE model instead of applying the method of ordinary least squares (OLS) because estimators of the former (FGLS) are more efficient with a large sample.

\subsubsection{Heteroskedasticity}

The problem of heteroscedasticity takes place when the variance of the error terms varies across observations. In order to neutralize the presence of heteroskedasticity in the FE result as it does not affect RE, robustness test was undertaken for validity of statistical inferences. The problem of heteroskedasticity in FE Model Result can be eliminated by applying the likelihood-ratio (LR) test procedure. However, FGLS fundamentally counterbalances the effect of heteroskedasticity. Hence, the use of FGLS results in this study for analysis.

\subsubsection{Multicollinearity Test}

Variance Inflation Factor (VIF) was estimated to detect any presence of multicollinearity. If the VIF of the variables fall between 1 and 10 or Tolerance Coefficients fall between 
$10 \%$ to less than $100 \%$, it is anticipated that the variables suffer no multicollinearity or have no elements of spuriousness because a statistical research model of tolerance coefficients that are not so close to zero, is deemed not to have a problem of multicollinearity, (Gujarati 1995). Maximum VIF of 1.96 does not imply critical multicollinearity, (Kennedy 2008).

\subsubsection{Serial Correlation}

Wooldridge Test for autocorrelation in panel data was also used to know whether there is a serial correlation. A significant test statistic implies presence of serial correlation in the result, (Drukker 2003).

\section{Result}

Here, the result of data analysis and hypothesis testing was presented. The outputs of descriptive statistics, correlation matrix table and subsequently, the summary of regression were also discussed. Necessary policy implications of the findings and recommendation were made.

\subsection{Summary Statistics}

Table 2. Descriptive Statistics.

\begin{tabular}{|c|c|c|c|c|c|}
\hline Variables & Obs & Mean & Std Dev. & Mini. & Maxi. \\
\hline Return on Asset (ROA) & 125 & 0.00967 & 0.04085 & -0.2964 & 0.09536 \\
\hline Capital Adequacy (cad) & 125 & 0.13768 & 0.07768 & -0.2329 & 0.30979 \\
\hline Credit Risk (crisk) & 125 & 0.05626 & 0.12324 & 0.00042 & 1.08452 \\
\hline Inflation (inf) & 126 & 3.3505 & 0.36304 & 2.8284 & 3.9887 \\
\hline
\end{tabular}

From Table 2 above, the mean value for Return on Assets is 0.009967 for the banks. The Capital Adequacy and Credit Risk have mean values of 0.13768 and 0.05626 while Inflation has a mean value of 3.3505. The minimum value for the Return on Assets is minus 0.2964 while the maximum is 0.09536 implying that there is greater management efficiency in using their assets to generate higher returns. Inflation recorded the highest standard deviation among the explanatory variables, which shows that it has the lowest contribution to the dependent variable (ROA).

\subsection{Multicollinearity}

Variance Inflation Factor (VIF) was estimated to detect any presence of multicollinearity. The VIF of the variables fell between 1 and 10 as shown in the appendix to the study, meaning that the variables suffer no multicollinearity because a statistical research model of tolerance coefficients that are not so close to zero, is deemed not to have a problem of multicollinearity (Gujarati, 1995). Low mean VIF of 1.21 was also obtained confirming the positions that maximum VIF of 1.96 does not imply critical multicollinearity, (Kennedy 2008).

\subsection{Correlation Matrix}

The table below presents the correlation values between the dependent variable and the independent variables and also the relationship between the independent variables themselves.

Table 3. Correlation Matrix.

\begin{tabular}{lllll}
\hline & ROA & CRISK & CAD & INF \\
\hline ROA & 1 & & & \\
CRISK & -0.6938 & 1 & & \\
CAD & 0.4828 & -0.4747 & 1 & \\
INF & -0.0239 & 0.1154 & -0.0255 & 1 \\
\hline
\end{tabular}

Source: Stata Output.

From the Table 3 above, the matrix shows that the relationship between the independent variables does not reveal any presence of the problem of multicollinearity. Multicollinearity occurs as a problem when the correlation is greater than 0.80 as stated by Kennedy (2008). All correlation coefficients below are less than 0.80 implying that the independent variable CRISK and INF had negative relationships with dependent variable (ROA) of listed Deposit Money Banks in Nigeria while CAD had a positive relationship with ROA of Listed Deposit Money Banks in Nigeria.

\section{Discussion}

\subsection{Feasible Generalized Least Square (FGLS) Regression}

Table 4 below shows the regression result of the dependent variable (ROA) and the independent variables of the study (CAD, RISK and INF). The analysis of the relationship and impact between the independent variables and the dependent variable used in this research work is presented hereunder together with the cumulative analysis.

Table 4. FGLS Regression Result.

\begin{tabular}{|c|c|c|c|c|}
\hline \multicolumn{5}{|c|}{ FGLS REGRESSION } \\
\hline Var & Co-eff & Std Error & Z-value & P-value \\
\hline cons & -0.01263 & 0.024367 & -0.52 & 0.604 \\
\hline cad & 0.103151 & 0.037264 & 2.77 & $0.006 * * *$ \\
\hline crisk & -0.20107 & 0.02364 & -8.51 & $0.000 * * *$ \\
\hline inf & 0.005803 & 0.007126 & 0.81 & 0.415 \\
\hline \multicolumn{5}{|c|}{ Coefficients: generalized least squares } \\
\hline \multicolumn{5}{|c|}{ Panels: homoskedastic } \\
\hline \multicolumn{5}{|c|}{ Correlation: no autocorrelation } \\
\hline \multicolumn{5}{|c|}{ Wald chi2 $(6)=132.38$} \\
\hline \multicolumn{5}{|c|}{ Prob $>$ chi $2=0.0000$} \\
\hline No. o & & 125 & & \\
\hline
\end{tabular}

Source: Panel estimation, 2008-2016 using Stata.

Note: $(* * * ; * ; *)=$ Significant at $1 \%, 5 \%$ and $10 \%$, respectively.

The table above summarizes the regression result, implying that capital adequacy and credit risk are significant at $1 \%$, while Inflation is not significant. The model is 
therefore estimated in the following way:

$$
\begin{gathered}
\mathrm{ROA}_{\mathrm{ij}}=-0.01263+0.103151 \mathrm{CAD}_{\mathrm{ij}}-0.20107 \mathrm{CRISK}_{\mathrm{ij}}+ \\
0.005803 \mathrm{INF}_{\mathrm{ij}}+\varepsilon
\end{gathered}
$$

The result shows a negative relationship between credit risk and return on assets (ROA), while a positive and significant relationship occurs between capital adequacy and ROA.

As expected, the effect of capital adequacy represented by equity to total assets (cad) showed a positive coefficient and significant at $1 \%$ on ROA, a measure of profitability. Basically, $1 \%$ change in equity fund obtained from shareholders leads to an increase in bank profitability by $10.32 \%$ while other factors are held constant. This implies that the banks under study can absorb losses and manage risk exposure with shareholders. This result is consistent with that of (Abreu and Mendes, 2001) and (Kosmidou, 2008).

As anticipated, the coefficient of credit risk measured by loan loss provision to total loans (crisk) revealed a negative and statistically significant at $1 \%$ level of significance on ROA of banks in Nigeria. A percentage increase in CRISK will lead to a decrease in bank profitability by $20.11 \%$ while other variables remain constant. This result is consistent with findings of (Ahmed, Riaz and Muhammad, 2012), (Fan, 2014), (Ishmael, 2015), (Manel, 2015) and (Melaku, 2016). So, there is a need for Nigeria to establish and maintain a central database called Credit Risk Management System across banks in the country, which would be generating accurate and reliable credit information on bank borrowers as a way of assessing the repayment capabilities of the customers to be granted credit facilities. This will definitely reduce the incidents of non-performing or abandoned loans in the banks under study.

The coefficient of inflation variable showed a positive and insignificant relationship with bank profitability. In line with the Economic theory on Inflation, the positive sign showed that the bank management was able to factor the impact of inflation anticipation in their cost structure, but the significance of such forecast on bank profitability was found to be fictional. As shown by our finding, the result of (Molyneux and Thorton, 1992), Idries, Khalifeh and Salaheddin (2010) and Oleka, Eyisi and Onyeze (2014) also revealed a positive impact of inflation on bank profitability.

\subsection{Test of Hypothesis}

This result produces an evidence of rejecting or not rejecting the null hypothesis.

$\mathrm{H}_{0}$ a: Capital Adequacy has no significant effect on the Profitability of Deposit Money Banks in Nigeria.

Based on the above FGLS estimations, there is a positive and significant relationship between capital adequacy and bank profitability $1 \%$ level of significance. Therefore, the null hypothesis is rejected as expected. This positive correlation between capital adequacy and bank profitability is consistent with previous studies of (Abreu and Mendes, 2001), (Kosmidou, 2008).

$\mathrm{H}_{0}$ b: Credit Risk has no significant effect on the Profitability of Deposit Money Banks in Nigeria. There was a negative and statistically significant relationship between credit risk and bank profitability as expected. Therefore, the null hypothesis is rejected. This is consistent with studies of (Ahmed, Riaz and Muhammad, 2012), (Fan, 2014), (Ishmael, 2015) and (Manel, 2015).

$\mathrm{H}_{0}$ c: Inflation has no significant effect on the Profitability of Deposit Money Banks in Nigeria. Inflation had no statistically significant relationship with bank profitability. So, the null hypothesis is accepted. This result is consistent with previous studies of (Molyneux and Thorton, 1992), Idries, Khalifeh and Salaheddin (2010) and Oleka, Eyisi and Onyeze (2014).

\begin{tabular}{|c|c|c|c|c|c|c|}
\hline VARIABLES & Coeff. & Std. Error & T-Test & P. Value & $\mathbf{H}_{0}$ & $\mathbf{H}_{0}$ \\
\hline Capital Adequacy (cad) & 0.1032 & 0.03726 & 2.77 & $0.006 * * *$ & & $\sqrt{ }$ \\
\hline Credit Risk (crisk) & -0.2011 & 0.02364 & -8.51 & $0.000^{* * *}$ & & $\sqrt{ }$ \\
\hline Inflation (inf) & 0.0058 & 0.00713 & 0.81 & 0.415 & $\sqrt{ }$ & \\
\hline
\end{tabular}

Table 5. The Summary of Hypotheses Testing.

\subsection{Policy Implication of the Findings}

The policy implications obtained from this study point to the significance of bank-specific factors in improving bank profitability in Nigeria. This study therefore serves as a guide for enhancing policies of Nigeria's banking sector. The signs of the factors affecting banks' profitability in Nigeria have crucial policy implications as described below:

i. Based on the research findings, capital adequacy was found to be significant. A positive sign of this variable could imply that banks in Nigeria have the ability to retain capital, absorb loan losses, support future growth of assets and also produce returns to shareholders. In ensuring that this is sustainable, banking sector regulators in Nigeria should ensure that banks hold adequate amount of reserves to be able to absorb losses and also mitigate the effect of adverse shocks to the economies. On a periodic basis, the regulators should conduct efficient and effective monitoring and supervision of banks under the Nation's control in terms of maintaining the minimum capital requirement for optimum utilization of resources and avoiding bank distress.

ii. The coefficient of loan loss provision to total loans, which is a proxy of credit risk showed a significant effect on bank profitability. The study also reported a negative sign. The implication of this sign is that the banks examined in this study had a high dissimilarity in terms of managing credit risk. Therefore, a strong credit risk policy should be put in place by the banks for greater profitability. The regulators of the banking industry in the country should also ensure that prudent credit risk management procedures are regularly maintained. Aside from that, there is a need for the regulators to be guiding against excessive risk-taking that could impair 
financial stability of the banks. The regulators should also promote policies that foster strong supervision of borrowers to avoid non-performing loans.

iv. Inflation was also found to be statistically insignificant. The coefficient of this variable was positively associated with bank profitability, which implies that the macroeconomic factor was anticipated by the management of the banks during the study period by adjusting interest rates accordingly so as to reduce the cost of inflation. In order to cushion the effect of inflation, bank managers in Nigeria can equally trade in bonds, derivatives and other securities that are in line with their business models for higher returns.

\section{Conclusion}

The study examined the determinants of the profitability of Deposit Money Banks in Nigeria. The capital adequacy, credit risk and inflation represent independent variables while dependent variable was proxy by Return on Assets (ROA). It was found that capital adequacy has a positive and significant effect on the Return on Assets (ROA) of listed Deposit Money Banks in Nigeria, whereas credit risk has a negative and significant influence on the Return on Assets (ROA) of listed Deposit Money Banks in Nigeria. Inflation, though used as a control variable in this study has a positive and insignificant effect on the Return on Assets (ROA) of listed Deposit Money Banks in Nigeria. Therefore, the result shows that bank-specific variables have strongly and significantly affected profitability of listed deposit money banks in Nigeria during the study period. Based on the study findings, it is recommended that the Central Banks should effectively regulate the capital and the resources owned by the Deposit Money Banks (DMBs) in Nigeria by ensuring that a certain level of capital is kept with the Central Bank of Nigeria $(\mathrm{CBN})$ for DMBs' financial soundness and stability. This will enable them to continue to absorb losses and manage risk exposure with shareholders.

It is also suggested that the Central Bank of Nigeria should uphold a central database called Credit Risk Management System across banks in the country, which would be generating accurate and reliable credit information on bank borrowers as a way of evaluating the repayment capabilities of the customers to be granted credit facilities. When this is put in place, it is believed that the incidents of nonperforming or abandoned loans in the banks under study will significantly decrease.

In line with the research findings above, the Deposit Money Banks were able to consider the effect of inflation in their operating activities. Nevertheless, the CBN should increase the reserve requirements of the banks under study so as to reduce inflation in the foreseeable future.

\section{Appendix}

Descriptive Statistics

\begin{tabular}{r|rrrrr} 
- summarize \\
Variable & obs & Mean & Std. Dev. & Min & Max \\
\hline index & 126 & 7.5 & 4.047221 & 1 & 14 \\
year & 126 & 2012 & 2.592296 & 2008 & 2016 \\
roa & 125 & .0096715 & .040852 & -.2964348 & .0953641 \\
cad & 125 & .1376753 & .0776842 & -.232947 & .3097899 \\
crisk & 125 & .0562615 & .1232395 & .0004183 & 1.08452 \\
\hline inf & 126 & 3.3505 & .3630386 & 2.8284 & 3.9887
\end{tabular}

Fixed Effect

\begin{tabular}{|c|c|c|c|c|c|c|}
\hline \multicolumn{4}{|c|}{$\begin{array}{l}\text { Fixed-effects (within) regression } \\
\text { Group variable: index }\end{array}$} & \multicolumn{2}{|c|}{$\begin{array}{l}\text { Number of obs } \\
\text { Number of groups }\end{array}$} & $\begin{array}{r}125 \\
14\end{array}$ \\
\hline $\begin{array}{ll}\text { R-sq: } & \text { within } \\
& \text { between } \\
\text { overa11 }\end{array}$ & $\begin{array}{l}=0.4636 \\
=0.7719 \\
=0.5143\end{array}$ & & & obs per & 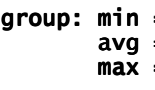 & $\begin{array}{r}8 \\
8.9 \\
9\end{array}$ \\
\hline $\operatorname{corr}\left(u_{-} i, x b\right)$ & $=0.0206$ & & & $\begin{array}{l}\mathrm{F}(3,108) \\
\text { Prob }>\mathrm{F}\end{array}$ & & $\begin{array}{r}31.12 \\
0.0000\end{array}$ \\
\hline roa & coef. & Std. Err. & $t$ & $P>|t|$ & {$[95 \%$ Conf } & . Interval] \\
\hline $\begin{array}{r}\text { cad } \\
\text { crisk } \\
\text { inf } \\
\text { cons }\end{array}$ & $\begin{array}{r}.0976917 \\
-.2020478 \\
-.0055798 \\
-.0110775\end{array}$ & $\begin{array}{l}.0443858 \\
.0260239 \\
.007345 \\
.025499\end{array}$ & $\begin{array}{r}2.20 \\
-7.76 \\
0.76 \\
-0.43\end{array}$ & $\begin{array}{l}0.030 \\
0.000 \\
0.452 \\
0.665\end{array}$ & $\begin{array}{r}.0097114 \\
-.2536316 \\
-.0090574 \\
-.0616209\end{array}$ & $\begin{array}{r}.185672 \\
-.150464 \\
.0202171 \\
.0394658\end{array}$ \\
\hline $\begin{array}{r}\text { sigma_u } \\
\text { sigma_e } \\
\text { rho }\end{array}$ & $\begin{array}{l}.00814304 \\
.02931318 \\
.07164129\end{array}$ & (fraction & f varia & ce due to & $\left.u_{-} i\right)$ & \\
\hline
\end{tabular}

Random Effect 
- xtreg roa cad crisk inf, re

Random-effects GLS regression Group variable: index

R-sq: $\quad$ within $=0.4635$
between $=0.7727$
overa11 $=0.5143$

Random effects $u_{-} i \sim$ Gaussian

$\operatorname{corr}\left(u_{-} i, X\right)=0$ (assumed)

$\begin{array}{llr}\text { Number of obs } & = & 125 \\ \text { Number of groups } & = & 14 \\ \text { Obs per group: } \min & = & 8 \\ \text { avg } & = & 8.9 \\ \max & = & 9 \\ & & 128.14 \\ \text { Wald chi2(3) } & = & 0.0000 \\ \text { Prob }>\operatorname{chi2} & = & \end{array}$

\begin{tabular}{|c|c|c|c|c|c|c|}
\hline roa & Coef. & Std. Err. & $\mathbf{z}$ & $P>|z|$ & [95\% Conf. & Interva1] \\
\hline $\begin{array}{r}\text { cad } \\
\text { crisk } \\
\text { inf } \\
\text { cons }\end{array}$ & $\begin{array}{r}.1031506 \\
-.2010737 \\
.005803 \\
-.0126304\end{array}$ & $\begin{array}{l}.0378749 \\
.0240274 \\
.0072432 \\
.0247664\end{array}$ & $\begin{array}{r}2.72 \\
-8.37 \\
0.80 \\
-0.51\end{array}$ & $\begin{array}{l}0.006 \\
0.000 \\
0.423 \\
0.610\end{array}$ & $\begin{array}{r}.0289171 \\
-.2481665 \\
-.0083935 \\
-.0611717\end{array}$ & $\begin{array}{r}.1773841 \\
-.1539809 \\
.0199995 \\
.0359108\end{array}$ \\
\hline $\begin{array}{r}\text { sigma_u } \\
\text { sigma_e } \\
\text { rho }\end{array}$ & $\begin{array}{r}0 \\
.02931318 \\
0\end{array}$ & (fraction & varia & ce due & $\left.u_{-} i\right)$ & \\
\hline
\end{tabular}

Hausman Test

- hausman fe

\begin{tabular}{|c|c|c|c|c|}
\hline & \multicolumn{2}{|l|}{$\longrightarrow$} & \multirow[b]{2}{*}{$\begin{array}{c}(b-B) \\
\text { Difference }\end{array}$} & \multirow[b]{2}{*}{$\begin{array}{c}\operatorname{sqrt}\left(\operatorname{diag}\left(V \_b-V \_B\right)\right) \\
\text { S.E. }\end{array}$} \\
\hline & $\begin{array}{l}\text { (b) } \\
\mathrm{fe}\end{array}$ & (B) & & \\
\hline $\begin{array}{r}\text { cad } \\
\text { crisk } \\
\text { inf }\end{array}$ & $\begin{array}{r}.0976917 \\
-.2020478 \\
.0055798\end{array}$ & $\begin{array}{r}.1031506 \\
-.2010737 \\
.005803\end{array}$ & $\begin{array}{r}-.005459 \\
-.0009741 \\
-.0002232\end{array}$ & $\begin{array}{l}.0231427 \\
.0099963 \\
.0014374\end{array}$ \\
\hline
\end{tabular}

b = consistent under Ho and $\mathrm{Ha}$; obtained from xtreg

$B=$ inconsistent under $\mathrm{Ha}$, efficient under Ho; obtained from xtreg

Test: Ho: difference in coefficients not systematic

$$
\begin{aligned}
\operatorname{chi2}(3) & = & (b-B)^{\prime}\left[\left(V_{-} b-V \_B\right) \wedge(-1)\right](b-B) \\
& = & 0.08 \\
\text { Prob }>\text { chi2 } & = & 0.9938
\end{aligned}
$$

Feasible Generalized Least Square (Fgls)

$$
\begin{aligned}
& \text { - xtgls roa cad crisk inf } \\
& \text { cross-sectional time-series FGLS regression } \\
& \text { Coefficients: generalized least squares } \\
& \text { Panels: homoskedastic } \\
& \text { Correlation: no autocorrelation }
\end{aligned}
$$

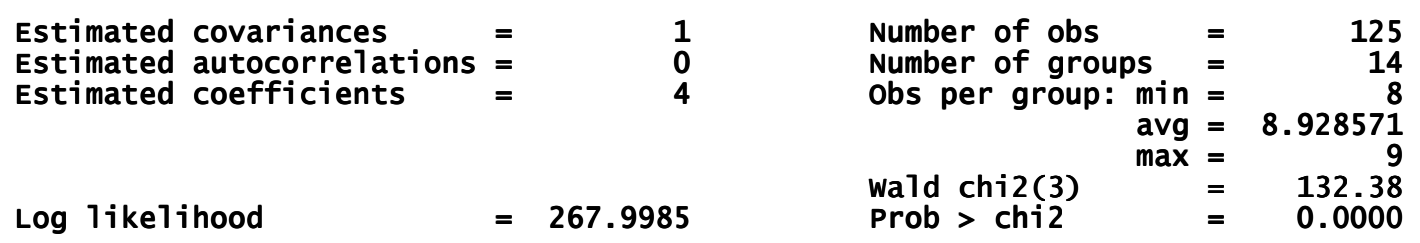

\begin{tabular}{r|rrrrrr}
\hline roa & Coef. & Std. Err. & $z$ & P $>|z|$ & [95\% Conf. Interval] \\
\hline cad & .1031506 & .037264 & 2.77 & 0.006 & .0301145 & .1761868 \\
crisk & -.2010737 & .0236398 & -8.51 & 0.000 & -.2474069 & -.1547405 \\
inf & .005803 & .0071264 & 0.81 & 0.415 & -.0081645 & .0197705 \\
_cons & -.0126304 & .0243669 & -0.52 & 0.604 & -.0603887 & .0351278 \\
\hline
\end{tabular}

Variance Inflation Factor (Vif) 


\begin{tabular}{|c|c|c|}
\hline Variable & VIF & $1 /$ VIF \\
\hline $\begin{array}{r}\text { crisk } \\
\text { cad } \\
\text { inf }\end{array}$ & $\begin{array}{l}1.31 \\
1.29 \\
1.01\end{array}$ & $\begin{array}{l}0.763962 \\
0.773775 \\
0.985568\end{array}$ \\
\hline Mean VIF & 1.21 & \\
\hline
\end{tabular}

Correlation Matrix

\begin{tabular}{|c|c|c|c|c|}
\hline & roa & crisk & cad & inf \\
\hline $\begin{array}{r}\text { roa } \\
\text { crisk } \\
\text { cad } \\
\text { inf }\end{array}$ & $\begin{array}{r}1.0000 \\
-0.6938 \\
0.4828 \\
-0.0239\end{array}$ & $\begin{array}{r}1.0000 \\
-0.4747 \\
0.1154\end{array}$ & $\begin{array}{r}1.0000 \\
-0.0255\end{array}$ & \\
\hline
\end{tabular}

List of Quoted Banks

Listed Banks on the Nigerian Stock Exchange

As at 31 st December, 2016

1. Access Bank Plc.

2. Diamond Bank Plc

3. Ecobank Transnational Incorporated

4. First Bank Of Nigeria (Fbn) Holdings Plc

5. FCMB Group Plc.

6. Fidelity Bank Plc

7. Guaranty Trust Bank Plc.

8. Skye Bank Plc

9. Stanbic Ibtc Holdings Plc

10.Sterling Bank Plc.

11.Union Bank Nig. Plc

12.United Bank For Africa Plc

13.Unity Bank Plc

14. Wema Bank Plc.

15.Zenith International Bank Plc

Sampled Listed Banks in Nigeria

1. Access Bank plc.

2. Diamond Bank plc.

3. First City Monument Bank plc.

4. Fidelity Bank plc.

5. First Bank plc.

6. GTB plc.

7. Skye bank plc.

8. Stanbic ibtc bank plc.

9. Sterling bank plc.

10.UBA plc.

11.Union bank plc.

12.Unity bank plc.

13. Wema bank plc.

14.Zenith bank plc.

\section{References}

[1] Abba Gabriel Ogere, Zachariah Peter and E. E Inyang (2013). Capital Adequacy Ratio and Banking Risks in the Nigeria Money Deposit Banks. Research Journals of Finance and Accounting. Vol. 4, No. 17.
[2] Abreu and Mendes, (2001). Commercial Bank Interest Margins and Profitability: Evidence for some EU countries.

[3] Abu Hanifa Noman, Sajeda Pervin, Mustafa Manir Chowdhury and Hasanul Banna (2015). The Effect of Credit Risk on the Banking Profitability: A Case on Bangladesh. Global Journal of Management and Business Research: C Finance. Volume 15 Issue 3 Version 1.0.

[4] Agbeja, O., Adelakun O. J. and Olufemi F. I. (2015). Capital Adequacy Ratio and Bank Profitability in Nigeria: A Linear Approach. International Journal of Novel Research in Marketing Management and Economics Vol. 2, Issue 3, pp: (91-99).

[5] Ahmad Aref Almazari (2013). Capital Adequacy, Cost Income Ratio and the Performance of Saudi Banks (2007-2011). International Journal of Academic Research in Accounting, Finance and Management Sciences Vol. 3, No. 4.

[6] Ahmad Nor Hayati and Ariff Mohamed (2007). Multi-country study of bank credit risk determinants. International Journal of Banking and Finance: 5(1), 6.

[7] Ahmed Raza ul Mustafa, Riaz Hussein Ansari and Muhammad Umair Youni (2012). Does The Loan Loss Provision Affect The Banking Profitability In Case Of Pakistan? Asian Economic and Financial Review 2(7).

[8] Akano Ajibola Isaac Kazeem Hammed Samuel and Luka Mailafia (2014). Internal Attributes and Profitability of Listed Deposit Banks in Nigeria. KASU Journal of Accounting Research and Practice, Vol.3 Issue 1.

[9] Alexis Arieff, Martin A. Weiss, Vivian C. Jones (2010). The Global Economic Crisis: Impact on Sub-Saharan Africa and Global Policy Responses. Congressional Research Service.

[10] Ani W. U., Ugwunta D. O., Ezeudu I. J. and Ugwuanyi, G. O. (2012): An empirical assessment of the determinants of bank profitability in Nigeria: Bank characteristics panel evidence: Journal of Accounting and Taxation Vol. 4(3).

[11] Anna P. I. Vong and Hoi Si Chan (2009). Determinants of Bank Profitability in Macao.

[12] Davydenko, Antonina (2011) "Determinants of Bank Profitability in Ukraine," Undergraduate Economic Review: Vol.7:Issue.1,Article2.Available at:http://digitalcommons.iwu.edu/uer/vol7/iss1/2 
[13] Aremu Mukaila Ayanda, Ekpo Imoh Christopher, Mustapha Adeniyi Mudashiru and Adedoyin Salami Isaac (2013). Determinants of Capital Structure in Nigerian Banking

[14] Sector, International Journal of Academic Research in Economics and Management Sciences. 2(4).

[15] Asikhia Olalekan and Sokefun Adeyinka, (2013). Capital Adequacy and Banks' Profitability: An Empirical Evidence from Nigeria. American International Journal of Contemporary Research Vol. 3 No. 10.

[16] Athanasoglou, P., Brissimis, N. \& Delis, D. (2005). Bankspecific, industry specific and macroeconomic determinants of bank profitability, Journal of International Financial Markets, Institutions \& Money.

[17] Ayşe Altıok Yılmaz (2013). Profitability of Banking System: Evidence from Emerging Markets. WEI International Academic Conference Proceedings Antalya, Turkey.

[18] Badi H. Baltagi (2005), Econometric Analysis of Panel Data: Third Edition. Bank profitability in Croatia. Economic Research-Ekonomska Istraživanja.

[19] Berger, A. N. (1995). The relationship between capital and earnings in banking. Journal of Money Credit and Banking 27, $432-456$.

[20] Berger, A. N. and Humphrey, D. B. (1997). Efficiency of financial institutions: international survey and directions for future research. European Journal of Operational Research, Vol 98, pp. 175-212.

[21] Calixte Ahokpossi (2013). Determinants of Bank Interest Margins in Sub-Saharan Africa. IMF Working Papers.

[22] Chioma Dorothy Oleka, Eyisi Adanma Sabina and M. I. Ebue (2015). Relationship between Inflation and Firms' Performance-Evidence from Nigeria. World Applied Sciences Journal 33 (5).

[23] Chris Maina Kiragu (2010). The Relationship between Profitability and Capital Adequacy of Deposit Money Banks in Kenya.

[24] Christos K. Staikouras and Geoffrey E. Wood (2011). The Determinants of European Bank Profitability. International Business \& Economics Research Journal Volume 3, Number 6.

[25] Christos Staikouras and Geoffrey E. Wood (2004). The Determinants of European Bank Profitability. International Journal of Economics and Business Research 3(6):57-68.

[26] Das Abhimaan and Saibal Ghosh (2006). Financial deregulation and efficiency: An empirical analysis of Indian banks during the post reform period, Review of Financial Economics. 15(3), 193-221.

[27] David M. Drukker (2003). Testing for serial correlation in linear panel-data models. Stata Journal, 3(2), 168-177.

[28] David, Michael, Robert and Abhay (2013). A Capital Adequacy Buffer Model. Economic Department.

[29] Deger Alper and Adem Anbar (2011). Bank Specific and Macroeconomic Determinants of Commercial Bank Profitability: Empirical Evidence from Turkey. Business and Economics Research Journal 2(2). 139-152.

[30] Ellen Gaston and In Won Song (2014). Supervisory Roles in
Loan Loss Provisioning in Countries Implementing IFRS. International Monetary Fund WP/14/170. IMF Working Paper.

[31] European Central Bank (2014). Banking Structures Report.

[32] European Central Bank (2010). Beyond ROE - How to Measure Bank performance. Appendix to the report on EU banking structures.

[33] Fadzlan Sufian and Royfaizal Razali Chong (2008). Determinants of Bank Profitability in a Developing Economy: Empirical Evidence from the Philippines. Asian Academy of Management Journal of Accounting and Finance. AAMJAF, Vol. 4, No. 2, 91-112.

[34] Fan Li and Yijun Zou (2014). The Impact of Credit Risk Management on Profitability of Deposit Money Banks: A Study of Europe.

[35] Fentaw Leykun Fisseha (2015). Meta Analysis on the Determinants Of Commercial Bank's Profitability: (A Conceptual Frame Work and Modelling). European Scientific Journal vol.11, No. 19

[36] Gerti Shijaku and Irini Kalluci (2013). Determinants of Bank Credit to the Private Sector: The Case of Albania. 9(48).

[37] Griffiths, B. (1977). Inflation: The Price of Property, London: Weidenfield and Nicolson Limited. London.

[38] Grygorenko, O. (2009). Effects of Price Setting on Bank Performance: The Case of Ukraine. MA in Economics Degree Thesis. Kyiv School of Economics. Available at: http://www.kse.org.ua/uk/about/library/ma-theses/2009/

[39] Gujarati D. N. (1995) Basic Econometrics, 3e.

[40] Hassan, M. K. and Bashir, A. H. (2005). Determinants of Islamic Banking Profitability. In Munawar Iqbal and Rodney Wilson (Eds.), Islamic Perspectives on Wealth Creation, Edinburgh: Edinburgh University Press.

[41] Herry Achmad Buchory (2015). Banking Profitability: How does the Credit Risk and Operational Efficiency Effect?

[42] Ibrahim Nandom Yakubu (2016). Bank-Specific and Macroeconomic Determinants of Deposit Money Banks' Profitability in Ghana. International Finance and Banking Vol. 3 , No. 2 .

[43] Idries M. Al-Jarrah, Khalifeh N. Ziadat and Salaheddin Y. ElRimawi (2010). The Determinants of the Jordanian's Banks Profitability: A Cointegration Approach. Jordan Journal of Business Administration, Volume 6, No. 2.

[44] Ifuero Osad Osamwonyi and Chijuka Ify Michael (2014). The Impact of Macroeconomic Variables on the Profitability of Listed Deposit Money Banks in Nigeria. European Journal of Accounting Auditing and Finance Research. 2(10), 85-95.

[45] Igor Jemric and Boris Vujcic (2002). Efficiency of Banks in Croatia: A DEA Approach. Working Papers. Croatian National Bank, Public Relations and Publishing Department.

[46] Ikpefan Ochei A. (2013), Capital adequacy, management and performance in the Nigerian Commercial bank (1986 - 2006). African Journal of Business Management, Vol. 7(30).

[47] Ishmael A. G. and Benjamin Amoah (2015). Determinants of Bank Profitability in Ghana. International Journal of Accounting and Financial Reporting. Vol. 5, No. 1 
[48] Iwedi Marshal \& Onuegbu Onyekachi (2014). Credit Risk and Performance of Selected Deposit Money Banks in Nigeria: An Empirical Investigation. European Journal of Humanities and Social Sciences Vol. 31, No.1.

[49] James Ayodele Owoputi, Olawale Femi Kayode and Felix Ademola Adeyefa (2014). Bank Specific, Industry Specific and Macroeconomic Determinants of Bank Profitability in Nigeria. European Scientific Journal. vol.10, No.25.

[50] Jim Wong, Eric Wong, Tom Fong and K. F. Choi (2006). Competition in Hong Kong's Banking Sector: A Panzar-Rosse Assessment. SSRN Electronic Journal.

[51] Joaquín Maudos and Juan Fernández de Guevara (2004). Factors explaining the Interest Margin in the Banking Sectors of the European Union.

[52] Johannes D. M. Mathuva, (2009). Capital Adequacy, Cost Income Ratio and the Performance of Deposit Money Banks: The Kenyan Scenario. The International Journal of Applied Economics and Finance, 3: 35-47. Journal of Accounting and Financial Reporting. Vol. 5, No. 1

[53] Johannes Peyavali Sheefeni Sheefeni (2015). Examining the Bank Specific Determinants of Profitability among Commercial Banks in Namibia. Global Advanced Research Journal of Management and Business Studies. 4(6) 216-226.

[54] John H. Boyd, Ross Levine and Bruce D. Smith (2000). The Impact of Inflation on Financial Sector Performance, Journal of Business and Management Sciences, Vol. 3, No. 4.

[55] Kennedy, Peter (2008). A Guide to Econometrics 6ed. Malden: Wiley-Blackwell.

[56] Khaled Abdalla Moh'd Al-Tamimi and Samer Fakhri Obeidat (2013). Determinants of Capital Adequacy in Commercial Banks of Jordan an Empirical Study. International Journal of Academic Research in Economics and Management Sciences. 2(4).

[57] Khalid Ashraf Chishty (2011). The Impact of Capital Adequacy Requirements on Profitability of Private Banks in India (A Case Study of J\&K, Icici, Hdfc and Yes Bank). International Journal of Research in Commerce \& Management. Volume No: 2, Issue No. 7.

[58] Kalluci I. (2011). Analysis of the Albanian banking system in a risk-performance framework, proceeding of $3^{\text {rd }}$ Annual South-Eastern European Economic Research Workshop.

[59] Kolapo T. Funso, Ayeni R. Kolade and Oke M. Ojo (2012). Credit Risk and Deposit Money Banks' Performance in Nigeria: a Panel Model Approach. Australian Journal of Business and Management Research Vol.2 No.02.

[60] Kristen Regehr and Rajdeep Sengupta (2016). Has the Relationship between Bank Size and Profitability Changed? Economic Review, Federal Reserve Bank of Kansas City.

[61] Kyriaki Kosmidou (2008). The determinants of banks' profits in Greece during the period of EU financial integration. Managerial Finance Vol.34 No.3.

[62] Lawrence Kusienyo (2011). The Determinants of Profitability of Banks in Ghana. A Thesis submitted to the Institute of Distance Learning, Kwame Nkrumah University of Science and Technology in partial fulfillment of the requirements for the degree of Commonwealth Executive Masters of Business Administration (CEMBA).
[63] Luc Laeven, Lev Ratnovski and Hui Tong (2014). Bank Size and Systemic Risk. International Monetary Fund, IMF Staff Discussion Note.

[64] Lucky Anyike Lucky and Nwosi, Anele Andrew (2015). Asset Quality and Profitability of Deposit Money Banks: Evidence from Nigeria. Research Journal of Finance and Accounting Vol.6, No.18.

[65] Maja Pervan, Iva Pelivan \& Josip Arnerić (2015) Profit persistence and determinants of bank profitability in Croatia, Economic Research-Ekonomska Istraživanja, 28:1, 284-298

[66] Manel Hadriche (2015). Banks Performance Determinants: Comparative Analysis between Conventional and Islamic Banks from GCC Countries. International Journal of Economics and Finance Vol. 7, No. 9.

[67] Matthew Osborne, Ana-Maria Fuertes and Alistair Milne (2013). Capital and profitability in banking: Evidence from US banks. Available at :https://www.cass.city.ac.uk/_data/assets/pdf_file/0013/15 2122/Osborne_Matthew_Capital-and-earnings-in-bankingEmerging-Scholars.pdf

[68] Mburu, Ruth Muthoni (2013). The Effect of Liquidity and Solvency on the Profitability of Commercial Banks in Kenya. Msc. Finance Degree Thesis. University of Nairobi, Kenya.

[69] Melaku, Aweke Merin (2016). Determinants of Bank Profitability in Ethiopia:A Case Study of Private Deposit Money Banks. Research Journal of Finance and Accounting Vol.7, No.7.

[70] Michael C. Jensen and William H. Meckling (1976). Theory of the Firm: Managerial Behavior, Agency Costs and Ownership Structure. Journal of Financial Economics, 3(4), 305-360.

[71] Million Gizaw, Matewos Kebede and Sujata, (2015). The Impact of Credit Risk on Profitability Performance of Deposit Money Banks in Ethiopia, African Journal of Business Management. 9(2), 59-66.

[72] Mohammad Suleiman Aladwan (2015). The Impact of Bank Size on Profitability: An Empirical Study on Listed Jordanian Deposit Money Banks. European Scientific Journal vol. 11, No. 34.

[73] Mohammad, Abdelkarim Almumani (2013). Impact of Managerial Factors on Commercial Bank Profitability: Empirical Evidence from Jordan. International Journal of Academic Research in Accounting, Finance and Management Sciences Vol. 3, No.3.

[74] Mohammad, Morshedur Raman, Kowsar Hamid and Abdul Mannan Khan (2015). Determinants of Bank Profitability: Empirical Evidence from Bangladesh. International Journal of Business and Management; Vol. 10, No. 8.

[75] Mohammed Umar, Danjuma Maijama'a and Mohammad Adamu (2014). Conceptual exposition of the effect of inflation on bank performance, Journal of World Economic Research 3(5).

[76] Philip Molyneux and John Thornton (1992). Determinants of European bank profitability: A note. Journal of Banking and Finance. 1173-I178.

[77] Moody's Investor Service (2011) Banking Account \& Ratio Definitions Moody's Investors Service. Available at:https://www.moodys.com/sites/products/ProductAttachment s/Banking\%20Account\%20and\%20Ratio\%20Definitions.pdf 
[78] Mohammed Amidu and Robert Hinson (2006). Credit Risk, Capital Structure and Lending Decisions of Banks in Ghana, Banks and Bank Systems/Volume 1, Issue 1.

[79] Muhammad Farhan Akhtar (2011). Factors Influencing the Profitability of Conventional Banks of Pakistan, Euro Journals Publishing, Inc. Issue 66.

[80] Muhammad, Jawad Ishfaq and Naeem ullah Khan (2015). Bank Profitability, Inflation and Cost Efficiency-A Case of Pakistani Banks. International Journal of Business and Management Review Vol. 3, No. 1, pp. 41-53.

[81] Munyambonera, Ezra Francis (2012): Determinants of Commercial Bank Performance in Sub-Saharan Africa. Faculty of Economics and Management Makerere University.

[82] Munyambonera, Ezra Francis (2013): Determinants of Commercial Bank Profitability in Sub-Saharan Africa, International Journal of Economics and Finance; Vol. 5, No. 9

[83] Mustafa M. Soumadi and Bassam Fathi Aldaibat (2012). Growth Strategy and Bank Profitability: Case of Housing Bank for Trade \& Finance, European Scientific Journal 8(22). $1857-7881$.

[84] Naser Hooshyari and Abdollah Pakdel Moghanloo (2015). Evaluating the impact of Inflation on profitability of banks, Kuwait Chapter of Arabian Journal of Business and Management Review Vol. 4, No. 9.

[85] Nawaf Ahmad Salem AlGhusin (2015). The Impact of Financial Leverage, Growth, and Size on Profitability of Jordanian Industrial Listed Companies, Research Journal of Finance and Accounting.

[86] Ndifon Ojong Ejoh and Ubana Ubi Iwara (2014). The Impact of Capital Adequacy on Deposit Money Banks' Profitability in Nigeria, Research Journal of Finance and Accounting, Vol. 5, No. 12.

[87] Okafor Chinonye, lkechukwu Kelikume and Umoren Adebimpe (2010). The Effect of Capital Adequacy on Banks' Performance: Evidencefrom Nigeria. Journal of Business Research, Fourth Edition, VOL. 4, Nos. $1 \& 2$.

[88] Olaoye Festus Oladipupo and Olarewaju Odunayo M (2015): Determinants of Deposit Money Banks' Profitability in Nigeria. Kuwait Chapter of Arabian Journal of Business and Management Review Vol. 4, No. 9.

[89] Olawale Femi Kayode et al. (2015). Credit Risk and Bank Performance in Nigeria. IOSR Journal of Economics and Finance Volume 6, Issue 2. Ver. II.

[90] Oleka D. Chioma, Eyisi S. Adanma and Onyeze N. Clementina (2014). Empirical Study of the Impact of Inflation on Bank Performance: Implication for Investment Decision Making in Banking Industry in Nigeria. Humanity \& Social Sciences Journal 9 (2).

[91] Olubisi, Friday Oluduro (2015): Academia Arena 2015; 7(1) http://www.sciencepub.net/academia.

[92] Onaolapo A. A. and Adebayo, E. O. (2012). Effect of Capital Adequacy on the Profitability of Nigerian Banking Sector, Journal of Money, Investment and Banking. Issue 24.

[93] Robert S. Pindyck and Daniel L. Rubinfeld (1991). Econometric Models and Economic Forecasts. Economics series. 3rd Edition, McGraw-Hill.
[94] Paolo, Saona Hoffmann (2011). Determinants of the Profitability of the US Banking Industry, International Journal of Business and Social Science Vol. 2 No. 22.

[95] Perry, P. (1992). Do Banks Gain or Lose From Inflation. Journal of Retail Banking, 14(2), 25-30. (2007-2011). International Journal of Academic Research in Accounting, Finance and Management Sciences Vol. 3, No. 4.

[96] Ryan Stever (2007). Bank size, credit and the sources of bank market risk. Bank for Samina Riaz (2013): Profitability Determinants of Deposit Money Banks in PaksitanProceedings of 6th International Business and Social Sciences Research Conference.

[97] Samuel Alemu (2015). Masters of Science (Accounting and Finance) Thesis, Addis Ababa University, Addis Ababa, Ethiopian.

[98] Samuel Hymore Boahene, Julius Dasah and Samuel Kwaku Agyei (2012). Credit Risk and Profitability of Selected Banks in Ghana, Research Journal of Finance and Accounting. Vol 3, No 7.

[99] Samy Ben Naceur (2003). The determinants of the Tunisian banking industry profitability: Panel Evidence. Universite Libre de Tunis, Department of finance. Working Paper 2003.

[100] Santoni G. J. (1986). The Effects of Inflation on Deposit Money Banks. Federal Reserve Bank of St. Louis. Global Policy Responses: Congressional Research Service 7-5700.

[101] Sara Kanwal and Muhammad Nadeem (2013). The Impact of Macroeconomic Variables on the Profitability of Listed Commercial Banks in Pakistan, European Journal of Business and Social Sciences, 2(9), pp 186-201.

[102] Sarawan Angklomkliew, Jason George and Frank Packer (2009). Issues and Developments in Loan Loss Provisioning: the Case of Asia. BIS Quarterly Review.

[103] Sayilgan G, Yildirim O (2009). Determinants of Profitability in Turkish Banking Sector: 2002-2007, International Research Journal of Finance and Economics, No 28, pp 207-214.

[104] Shehu Usman Hassan and Abubakar Ahmed (2012). Ownership Structure and Oppurtunistic Accounting: A Case of Listed Food and Beverage Firms in Nigeria. International Journal of Physical and Social Sciences, Volume 2, Issue 7

[105] Shehu Usman Hassan and Musa Adeiza Farouk (2014). Firm Attributes and Earnings Quality of listed Oil and Gas Companies in Nigeria, Research Journal of Finance and Accounting. Vol. 5, No. 17.

[106] Stephen Oluwafemi Adeusi, Funso Tajudeen Kolapo and Adewale Olufemi Aluko (2014). Determinants of Deposit Money Banks' Profitability Panel Evidence from Nigeria. International Journal of Economics, Commerce and Management United Kingdom Vol. II, Issue 12.

[107] Tamim Mahamud Foisal, Anamul Haque and Ashraful Alam (2016). Determinants of Profitability-A Case from the Stateowned Deposit Money Banks of Bangladesh. European Journal of Business and Management, Vol. 8, No. 10.

[108] Terence McNamee and Mark Pearson and Wiebe Boer (2015). Africans Investing in Africa Understanding Business and Trade, Sector by Sector.

[109] Tesu Ramona (2013). BASEL I, II, III: Challenges to the Bank's Capital Adequacy. JEL Classifications: G21 2nd Issue. 
[110] Tuzcu SE (2015). The Effect of Derivatives Activity on Bank Profitability Before and During The Subprime Mortgage Crisis: Evidence from Turkey', Ankara Üniversitesi Sosyal Bilimler Dergisi.

[111] Valentina Flamini, Calvin MCDonald and Liliana Schumacher (2009): The Determinants of Commercial Bank Profitability in Sub-Saharan Africa. IMF Working Paper.

[112] William Bentum (2012). The Determinants of Profitability of the Deposit Money Banks in Ghana during the Recent Years of Global Financial Crisis, Master Thesis. Aarhus School of Business.
[113] Xuezhi Qin and Dickson Pastory (2012). Deposit Money Banks Profitability Position: The Case of Tanzania. International Journal of Business and Management; Vol. 7, No. 13.

[114] Yong Tan \& Christos Floros (2012). Bank profitability and GDP growth in China: A Note. Journal of Chinese Economic and Business Studies Volume 10, Issue 3.

[115] http://www.nigerianstockexchange.com/Issuers-section/listedsecurities 